\title{
Front Matter: Volume 11868
}

, "Front Matter: Volume 11868," Proc. SPIE 11868, Emerging Imaging and Sensing Technologies for Security and Defence VI, 1186801 (5 October 2021); doi: $10.1117 / 12.2614946$

SPIE. Event: SPIE Security + Defence, 2021, Online Only 


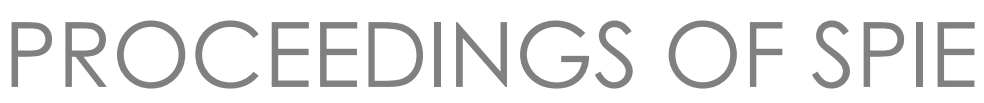

\title{
Emerging Imaging and Sensing Technologies for Security and Defence VI
}

\author{
Gerald S. Buller \\ Richard C. Hollins \\ Robert A. Lamb \\ Martin Laurenzis \\ Editors
}

13-17 September 2021

Online Only, Spain

Sponsored by

SPIE

Cooperating Organisations

European Optical Society • Cranfield University (United Kingdom) • CENSIS (United Kingdom)

- SEDOPTICA (Spain)

Supporting Organisation

INEUSTAR/INDUCIENCIA (Spain)

Published by

SPIE

Volume 11868 
The papers in this volume were part of the technical conference cited on the cover and title page. Papers were selected and subject to review by the editors and conference program committee. Some conference presentations may not be available for publication. Additional papers and presentation recordings may be available online in the SPIE Digital Library at SPIEDigitalLibrary.org.

The papers reflect the work and thoughts of the authors and are published herein as submitted. The publisher is not responsible for the validity of the information or for any outcomes resulting from reliance thereon.

Please use the following format to cite material from these proceedings:

Author(s), "Title of Paper," in Emerging Imaging and Sensing Technologies for Security and Defence VI, edited by Gerald S. Buller, Richard C. Hollins, Robert A. Lamb, Martin Laurenzis, Proc. of SPIE 11868, Seven-digit Article CID Number (DD/MM/YYYY); (DOI URL).

ISSN: 0277-786X

ISSN: 1996-756X (electronic)

ISBN: 9781510645806

ISBN: 9781510645813 (electronic)

Published by

SPIE

P.O. Box 10, Bellingham, Washington 98227-0010 USA

Telephone +13606763290 (Pacific Time)

SPIE.org

Copyright @ 2021 Society of Photo-Optical Instrumentation Engineers (SPIE).

Copying of material in this book for internal or personal use, or for the internal or personal use of specific clients, beyond the fair use provisions granted by the U.S. Copyright Law is authorized by SPIE subject to payment of fees. To obtain permission to use and share articles in this volume, visit Copyright Clearance Center at copyright.com. Other copying for republication, resale, advertising or promotion, or any form of systematic or multiple reproduction of any material in this book is prohibited except with permission in writing from the publisher.

Printed in the United States of America by Curran Associates, Inc., under license from SPIE.

Publication of record for individual papers is online in the SPIE Digital Library.

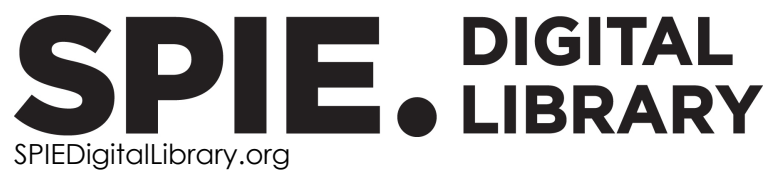

Paper Numbering: A unique citation identifier (CID) number is assigned to each article in the Proceedings of SPIE at the time of publication. Utilization of CIDs allows articles to be fully citable as soon as they are published online, and connects the same identifier to all online and print versions of the publication. SPIE uses a seven-digit CID article numbering system structured as follows:

- The first five digits correspond to the SPIE volume number.

- The last two digits indicate publication order within the volume using a Base 36 numbering system employing both numerals and letters. These two-number sets start with 00, 01, 02, 03, 04, 05, 06, 07, 08, 09, 0A, OB ... 0Z, followed by 10-1Z, 20-2Z, etc. The CID Number appears on each page of the manuscript. 


\section{Contents}

ADVANCES IN IMAGING

1186804 Mid-infrared photon counting LIDAR using intra-cavity up-conversion (Invited Paper) [1 1868-1]

1186805 Passive imaging of single photon flux: strategies for de-noising, motion blur reduction and super-resolution up-scaling [11868-2]

1186807 Quantum lidar using stationary broadband light [1 1868-4]

\section{COMPONENTS FOR IMAGING}

1186809 Detection and localization of near infrared lasers from atmospheric laser scattering (Invited Paper) [11868-6]

$118680 \mathrm{~A}$ A universal software framework for the assessment of compressed sensing algorithms [1 1868-7]

$118680 \mathrm{C} \quad$ Multispectral thermal camera using copper plasmonics [1 1868-9]

\section{QUANTUM TECHNOLOGIES}

11868 OF QCalc: a tool to compute classical and quantum communication rates over free-space optical channels [11868-13]

11868 OG GaN laser diodes for cold-atom quantum sensors and optical atomic clocks [11868-14]

$11868 \mathrm{OH}$ Practical security analysis against the Trojan-horse attacks on fiber-based phase-coding QKD system in the wide spectral range [11868-15]

11868 ol Random flip-flop: adding quantum randomness to digital circuits for improved cyber security, artificial intelligence and more [11868-16]

\section{MILLIMETRE WAVE AND TERAHERTZ SENSORS AND TECHNOLOGY}

$118680 \mathrm{M}$ Close range ISAR imaging with target velocity determination for security screening applications [11868-20]

$11868 \mathrm{ON}$ Imaging resolution enhancement using terajet effect at $0.3 \mathrm{THz}$ [11868-21] 
11868 OP Indoor passive sensing for detecting hidden objects under clothing [1 1868-23]

$118680 Q \quad$ Circularly polarized imaging for passive millimeter-wave security screening [11868-24]

11868 OS Terahertz-to-infrared converter based on the polyvinylchloride matrix with embedded gold nanoparticles [1 1868-26]

OPTICAL MATERIALS AND BIOMATERIALS IN SECURITY AND DEFENCE SYSTEMS TECHNOLOGY

11868 OV Infrared lenses using a novel infrared transmitting glass [1 1868-29]

POSTER SESSION

1186811 Development of a methodology for the formation of surface systems with programmable nanostructure parameters for effective use in modern manufacturing [1 1868-35]

1186812 A new method for determining surface roughness based on the improvement of the kinematics of the milling cutter movement during micro-cutting [1 1868-36]

$1186813 \quad$ New method for detecting active infeed of cutting edge of end mills [11868-37] 